\title{
Corruption Risk Analysis at the Project Planning Stage in the Iraqi Construction Sector using the Bowtie Methodology
}

\author{
Semaa Hazim Najim Alani \\ Civil Engineering Department \\ University of Baghdad \\ Baghdad, Iraq \\ S.Najim0901@coeng.uobaghdad.edu.iq
}

\author{
Ahmed Mohammed Raoof Mahjoob \\ Civil Engineering Department \\ University of Baghdad \\ Baghdad, Iraq \\ ahmed.mahjoob@coeng.uobaghdad.edu.iq
}

\begin{abstract}
In this paper, the bowtie method was utilized by a multidisciplinary team in the Federal Board of Supreme Audit (FBSA)for the purpose of managing corruption risks threatening the Iraqi construction sector. Corruption in Iraq is a widespread phenomenon that threatens to degrade society and halt the wheel of economic development, so it must be reduced through appropriate strategies. A total of eleven corruption risks have been identified by the involved parties in corruption and were analyzed by using probability and impact matrix and their priority has been ranked. Bowtie analysis was conducted on four factors with high score risk in causing corruption in the planning stage. The number and effectiveness of the existing proactive measures to prevent threats from resulting in corruption and were examined for each threat.
\end{abstract}

Keywords-corruption risk; bowtie; prevention; risk analysis

\section{INTRODUCTION}

Corruption is an old phenomenon that threatens the administrative apparatus in Iraq. As it was stated in the reports of Transparency International [1], Iraq is third among 180 countries in corruption and the phenomenon is increasing. The phenomenon of corruption largely stands in the way of the process of construction and progress at all economic levels. It costs money, time, energy, and impedes the performance of responsibilities and the fulfillment of jobs and services. Corruption can be defined as a social habit which is deeprooted in mankind's history. It is considered to be comparable to other crime types, which occur likely in the procurement of works through local authorities along with the complexity to monitor the expenditures of a project [2]. Authors in [3] provided a thorough overview of the corruption causes from certain studies in identified construction management journals for addressing the already-indicated issues. Forty-four corruption causes were indicated from a total of 37 publications and were examined with regard to current corruption factors, thematic categorizations of observed variables, and yearly trends of publications. The major causes were bad professionalism, ethical standards, close relationships, bad working and industrial conditions, insufficient sanctions, and bad role models. Authors in [4] identified factors which lead to fraudulent practices in every stage of the construction life Corresponding author: Semaa Hazim Najim Alani cycle. Those extracted fraudulent aspects have been mapped into a matrix form for checking the factor's similarities. A total of 42 contributing factors were verified and divided into 5 phases of the construction project life-cycle. With regard to the frequency, the main factors with regard to each stage were project approvals in the stage of planning, collusions between public officers and tenderers in the stage of design and tendering, insufficient compliances with the design for audit and report in the stage of construction, avoiding difficulties in the contract inspections in the stage of finishing, and utilizing sub-standard materials and services in the stage of maintenance.

\section{LITERATURE REVIEW}

Corruption is one of the biggest problems the governments face and it stands as an obstacle to sustainable development. Most projects in Iraq have suffered high deviations in cost, time, and quality which lead to wasting public money through exploiting public officers or authorities to achieve personal benefits that destroy the country's economy. Authors in [5] proposed a model for the performance and application control of rational decision-making with the best use of available resources and ongoing performance monitoring at all stages of the implementation of projects in order to eliminate aspects of financial and administrative corruption and reduce wastage in one of the most important formations carried out by the government in Iraq. Authors in [6] developed an Artificial Neural Network (ANN) model for assessing the collusion risks in the construction projects in China. The ANN has been utilized in a real life metro project, while the evaluated results established a complete framework regarding the collusive practices in the construction projects in China, that includes a total of 20 collusive practices associated with all the contracting entities. Authors in [7] presented the critical risk factors for design-build projects in the construction industry in Vietnam, factors affecting the on schedule implementation completion. The top 3 critical risk factors were: delays in project approval and licensing, interest rate fluctuations, and design or technical specifications deficiency and changes. Authors in [8] stated time overrun in construction projects is a very dangerous issue in developed countries. A quantitative 
approach was adopted to present the main causes of time overrun in the construction projects in Pakistan and the RIW (Relative Importance Weight) approach was used for collecting data.

The precise beginnings of the bowtie method are unclear [9], but it probably was originated in the 1970 s via the Imperial Chemical Industries (ICI). The first company integrating bowties totally in business practices is the Royal Dutch/Shell Group. Now, the use of bowties has been spread between nations, industries, and companies. Authors in [10] indicated that the bowtie analysis is a qualitative risk-assessment methodology providing an approach of efficient communication in complicated risk situations in simple graphical formats that shows the relations between damage escalation potential and the unwanted events' causes.

\section{Methodology}

The methodology that will be used in this paper is as follows:

- Identification of the corruption risks during the conception (planning) stage, which actually occurred in some completed construction projects by reviewing the Quarterly reports of the FBSA of projects from 2004-2013 and after some interviews with construction industry experts.

- Distribution of a prepared questionnaire on the FBSA staff in order to determine the probability and the effect of such risks.

- Implementing qualitative risk analysis on the corruption risks by using a probability - impact matrix to identify the priority of these risks.

- Application of bowtie methodology on these risks (threats).

\section{RISK RATING}

\section{A. Risk Probability}

For each of the risk occurrences, the probability must be set at a single value which is representing the best team judgment from the provided available data. In addition, the team must not be considering the effect while assessing the probability. The probability values and terms utilized in a 5-point scale to suit the likelihood of getting the risk can be seen in Table I [11]. Other classifications can be used according to what suits a project.

TABLE I. RISK PROBABILITY

\begin{tabular}{|l|c|c|}
\hline \multicolumn{1}{|c|}{ Term } & Value & Risk probability (\%) \\
\hline (1) Very high & 0.9 & $>70$ \\
\hline (2) High & 0.7 & $50-70$ \\
\hline (3) Moderate & 0.5 & $30-50$ \\
\hline (4) Low & 0.3 & $10-30$ \\
\hline (5) Very low & 0.1 & $0-10$ \\
\hline
\end{tabular}

\section{B. Risk Impact}

The risk impact is measuring the consequences on the project when a risk occurs. A scale that is comparable to the one of risk probabilities should be set up with regard to risk impact (Table II [12]).

\begin{tabular}{|l|c|}
\multicolumn{1}{c|}{ TABLE II. } & RISK IMPACT \\
\hline \multicolumn{1}{c|}{ Term } & Value \\
\hline (1) Very high & 0.8 \\
\hline (2) High & 0.4 \\
\hline (3) Moderate & 0.2 \\
\hline (4) Low & 0.1 \\
\hline (5) Very low & 0.05 \\
\hline
\end{tabular}

\section{Probability and Impact Matrix}

A probability and impact matrix has been utilized for looking up a combined risk rating, also referred to as the risk score, with regard to specific combinations related to probability and impact values. In addition, the score was utilized for prioritizing the risks for later activities of risk management. A graphical probability and impact matrix is efficiently communicating the relative severity regarding risk scores. The module is addressing the details regarding evaluating the risks and impacts, along with the way for applying such measures. Furthermore, a measure regarding the risk effect might be evaluated via multiplying risk probability (P) by risk impact (I) for producing risk score (RS) with regard to each one of the risks.

$$
\mathrm{RS}=\mathrm{P} \times \mathrm{I}
$$

In the heat map of Figure 1, the resulting high risks are colored red, the moderate risks yellow, and the low risks green [12].

\begin{tabular}{|c|c|c|c|c|c|}
\hline Probability & \multicolumn{5}{|c|}{ Threats } \\
\hline $\begin{array}{c}0.9 \\
\text { Very high }\end{array}$ & 0.05 & 0.09 & 0.18 & 0.38 & 0.72 \\
\hline $\begin{array}{c}0.7 \\
\text { High }\end{array}$ & 0.04 & 0.07 & 0.14 & 0.28 & 0.56 \\
\hline $\begin{array}{c}0.5 \\
\text { Moderate }\end{array}$ & 0.03 & 0.05 & 0.10 & 0.12 & 0.4 \\
\hline $\begin{array}{c}0.3 \\
\text { Low }\end{array}$ & 0.02 & 0.03 & 0.06 & 0.12 & 0.24 \\
\hline $\begin{array}{c}0.1 \\
\text { Very low }\end{array}$ & 0.01 & 0.01 & 0.02 & 0.04 & 0.08 \\
\hline & $\begin{array}{c}0.05 \\
\text { Very } \\
\text { low }\end{array}$ & $\begin{array}{c}0.1 \\
\text { Low }\end{array}$ & $\begin{array}{c}0.2 \\
\text { Moderate }\end{array}$ & $\begin{array}{c}0.4 \\
\text { High }\end{array}$ & $\begin{array}{c}0.8 \\
\text { Very } \\
\text { high }\end{array}$ \\
\hline
\end{tabular}

High (Red) / Med (YEL)/ low (GRN)

Fig. 1. Probability and impact matrix (heat map).

\section{The Questionnaire}

A questionnaire survey has been carried out for obtaining perception-based data related to corruption measurement items from 2 viewpoints, which are (1) probability (the occurrence possibility regarding each one of the measurement items), and (2) severity (the consequence's impact regarding each one of the measurement items), with the use of a 5-point Likert scale from 1 for very high to 5 for very low. About 60 questionnaire forms about corruption risk were distributed by hand to resident engineer's offices of FBSA projects in Iraq. Twenty two answered forms were not considered because they were partially answered and 8 were not received. A total of 30 answered questionnaires were considered. The responders belong to senior management staff, having 8 to 40 years of 
experience. Table III shows some details about the questionnaire responders whose responses were considered in this study.

\section{E. Responders Characteristics Summary}

Table III shows the experience of the respondents, Table IV their level of education, and Table V the scientific areas of their education.

TABLE III. RESPONDENTS' EXPERIENCE

\begin{tabular}{|c|c|c|c|}
\hline No. & Experience (years) & Frequency & $\mathbf{\%}$ \\
\hline 1 & $8-14$ & 8 & 27 \\
\hline 2 & $15-18$ & 15 & 50 \\
\hline 3 & $20-22$ & 3 & 10 \\
\hline 4 & $36-40$ & 4 & 13 \\
\hline & Total & 30 & $100 \%$ \\
\hline
\end{tabular}

TABLE IV. RESPONDENTS' LEVEL OF EDUCATION

\begin{tabular}{|c|c|c|c|}
\hline No. & Level of education & Frequency & $\mathbf{\%}$ \\
\hline 1 & B.Sc. & 18 & 60 \\
\hline 2 & Diploma & 1 & 3 \\
\hline 3 & M.Sc. & 7 & 23 \\
\hline 4 & Ph.D. & 2 & 7 \\
\hline 5 & CPA & 2 & 7 \\
\hline & total & 30 & $100 \%$ \\
\hline
\end{tabular}

TABLE V. RESPONDENTS' SCIENTIFIC AREAS

\begin{tabular}{|c|c|c|c|}
\hline No. & Area & Frequency & \% \\
\hline 1 & Civil Engineering & 15 & 50 \\
\hline 2 & Mechanical Engineering & 4 & 13.33 \\
\hline 3 & Electrical Engineering & 2 & 6.67 \\
\hline 4 & Architecture Engineering & 1 & 3.33 \\
\hline 5 & Law & 5 & 16.67 \\
\hline 6 & Control and Auditing & 2 & 6.67 \\
\hline 7 & Accounting & 1 & 3.33 \\
\hline & Total & 30 & 100 \\
\hline
\end{tabular}

\section{RESUlts}

The areas of risk concern at the stage of planning came from project documents and are provided in Table VI and Figure 2.

We can see that the CR3 (the estimated cost of the project compared to the building area was exaggerated) is ranked at the first place with a risk score of 0.4196 , which makes it a high risk rating. This result is in contrast with the findings in [15]. The second ranked risk is CR2 (there is a lack of a careful study of the estimated cost of the project within the feasibility study report), scoring 0.3067 , which also makes it a high risk which leads to inaccurate cost estimations of the project. This result is in line with the findings of [14]. The third risk CR6 (there is no ownership of the land on which the project is located, and some lands were transgressed) scored 0.1956, which is also a high risk rating, in line with the findings in [2]. The fourth risk is CR1 (there is no technical and economic feasibility study to the project) that scored 0.182 , which is a high risk rating, and is one of the requirements for approving the financial allocations for the implementation of any project. This result is in contradiction to Article (A-3) of the instructions for implementation of governmental contracts No. 1 in 2008 [13] and is line with the findings of [15].
TABLE VI. CORRUPTION RISKS RATING IN THE PLANNING STAGE

\begin{tabular}{|c|c|c|c|c|c|}
\hline ID & $\begin{array}{c}\text { Involved } \\
\text { parties }\end{array}$ & Corruption risk & $\begin{array}{l}\text { Risk } \\
\text { score }\end{array}$ & $\begin{array}{c}\text { Risk } \\
\text { rating }\end{array}$ & Rank \\
\hline CR1 & Client & $\begin{array}{l}\text { No technical and economic } \\
\text { feasibility study to the } \\
\text { project. }\end{array}$ & 0.182 & High & 4 \\
\hline CR2 & Client & $\begin{array}{l}\text { There is a lack of a careful } \\
\text { study of the estimated cost } \\
\text { of the project within the } \\
\text { feasibility study report. }\end{array}$ & 0.3067 & High & 2 \\
\hline CR3 & Client & $\begin{array}{l}\text { The estimated cost of the } \\
\text { project compared to the } \\
\text { building area } \\
\text { exaggerated. }\end{array}$ & 0.4196 & High & 1 \\
\hline CR4 & Client & $\begin{array}{l}\text { The technical and economic } \\
\text { feasibility study has not } \\
\text { been sent out to the } \\
\text { Ministry of Planning for the } \\
\text { purpose of obtaining } \\
\text { approval to include the } \\
\text { project in the investment } \\
\text { budget table. }\end{array}$ & 0.0472 & Low & 9 \\
\hline CR5 & Client & $\begin{array}{l}\text { There is no holistic vision } \\
\text { in the department about the } \\
\text { project requirements to be } \\
\text { translated and escalated } \\
\text { according to a careful } \\
\text { planning process into } \\
\text { engineering plans. }\end{array}$ & 0.1469 & Moderate & 7 \\
\hline CR6 & Client & $\begin{array}{l}\text { There is no ownership of } \\
\text { the land on which the } \\
\text { project is located, and some } \\
\text { lands were transgressed }\end{array}$ & 0.1956 & High & 3 \\
\hline CR7 & Client & $\begin{array}{l}\text { The work is divided into } \\
\text { several contracts and a } \\
\text { feasibility study is prepared } \\
\text { with an estimated cost for } \\
\text { each contract, even though } \\
\text { the project was included in } \\
\text { the ministry's plan } \\
\text { according to one feasibility } \\
\text { study and one holistic cost. }\end{array}$ & 0.176 & Moderate & 5 \\
\hline CR8 & Client & $\begin{array}{l}\text { A technical study has not } \\
\text { been prepared about the } \\
\text { contracting party's ability } \\
\text { to provide the necessary } \\
\text { staff. }\end{array}$ & 0.0261 & Low & 11 \\
\hline CR9 & $\begin{array}{c}\text { Client, } \\
\text { consultant }\end{array}$ & $\begin{array}{l}\text { Soil was investigated for } \\
\text { the project long before the } \\
\text { work was carried out. This } \\
\text { leads to geological changes } \\
\text { to the site's soil, and this } \\
\text { causes these investigations } \\
\text { mismatch the reality of the } \\
\text { project. }\end{array}$ & 0.1493 & Moderate & 6 \\
\hline CR10 & Client & $\begin{array}{lcr}\text { Project } & \text { planning } & \text { that } \\
\text { requires } & \text { a } & \text { true } \\
\text { contemplation and practical } \\
\text { forecasting is poor. }\end{array}$ & 0.0496 & Low & 8 \\
\hline CR11 & Client & $\begin{array}{l}\text { The project in the } \\
\text { investment budget is } \\
\text { included before specifying } \\
\text { estimated and total costs of } \\
\text { the project that was later } \\
\text { completed. }\end{array}$ & 0.0271 & Low & 10 \\
\hline
\end{tabular}

The fifth risk is CR7 (the work is divided into several contracts and a feasibility study is prepared with an estimated cost for each contract, even though the project was included in 
the ministry's plan according to one feasibility study and one holistic cost) that scored 0.176 which is a moderate risk rating. This result is in line with the findings in [2]. The sixth risk is CR9 (soil was investigated for the project long before the work was carried out), scoring 0.1493 which is a moderate risk rating. This result is in line with the findings in [2]. The seventh risk is CR5 (there is no holistic vision in the department about the project requirements to be translated and escalated according to a careful planning process into engineering plans) that scored 0.1469 which is a moderate risk rating. This result is in line with the findings in [15].

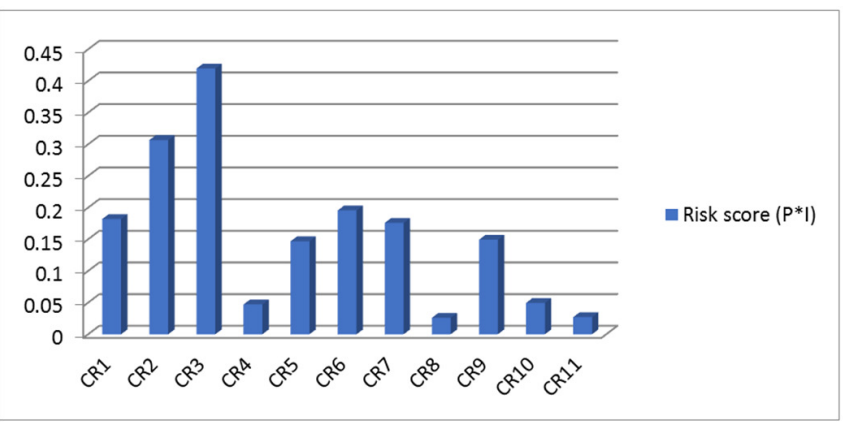

Fig. 2. The risk score for the corruption risk in planning stage.

The other risks have low risks ratings. CR10 (project planning that requires a true contemplation and practical forecasting is poor) scored 0.0496, CR4 (the technical and economic feasibility study has not been sent out to the Ministry of Planning for the purpose of obtaining approval to include the project in the investment budget table) scored 0.0472 in line with the findings in [2], CR11 (the project in the investment budget is included before specifying estimated and total costs of the project that was later completed-in contradiction to the instructions for implementation of governmental contracts (No. 1) in 2008 that stated that an updated study on the estimated cost or the required contract to be executed within the feasibility study for the purpose is to be used as a standard when analyzing bids and awarding contracts) scored 0.0271 , and CR8 (a technical study has not been prepared about contracting party's ability to provide the necessary staff) scored 0.0261 .

\section{APPLICATION OF BOWTIE XP ON THE CORRUPTION RISK}

After identifying the probability and impact (consequence) for each risk, the corruption risks in the planning stage of construction project were ranked. It was adopted that the risks with low and moderate rating can usually be managed using routine procedures, and the BowTie XP software [16] was applied on the risks with high rating. In a bowtie, the representation is that a threat (on diagram's left hand side) causes the top event (hazard release), which results in a consequence (harm to someone of something). We than have the opportunity to put in preventive barriers on diagram's left hand side to prevent the hazards, and barriers on diagram's right hand side to mitigate the harm from occurring. Practical recommendations for combating or eliminating the identified hazards were led via applying bowtie methodology, which leads to excellent understanding regarding the hazard protection and prevention needed for corruption risks in the sector construction. The causal factors that were used in BowTie XP to manage corruption risks threatening the construction sector in the planning stage were identified by a multidisciplinary team in the FBSA as the prevention barrier, effectiveness, and barrier type for each causal factor (threat), and corrective barrier, effectiveness, and barrier type for each consequence as shown in Figure 3.

To the best of our knowledge, the current research is the first one that uses the application of bowtie methodology with corruption risk in the construction sector.

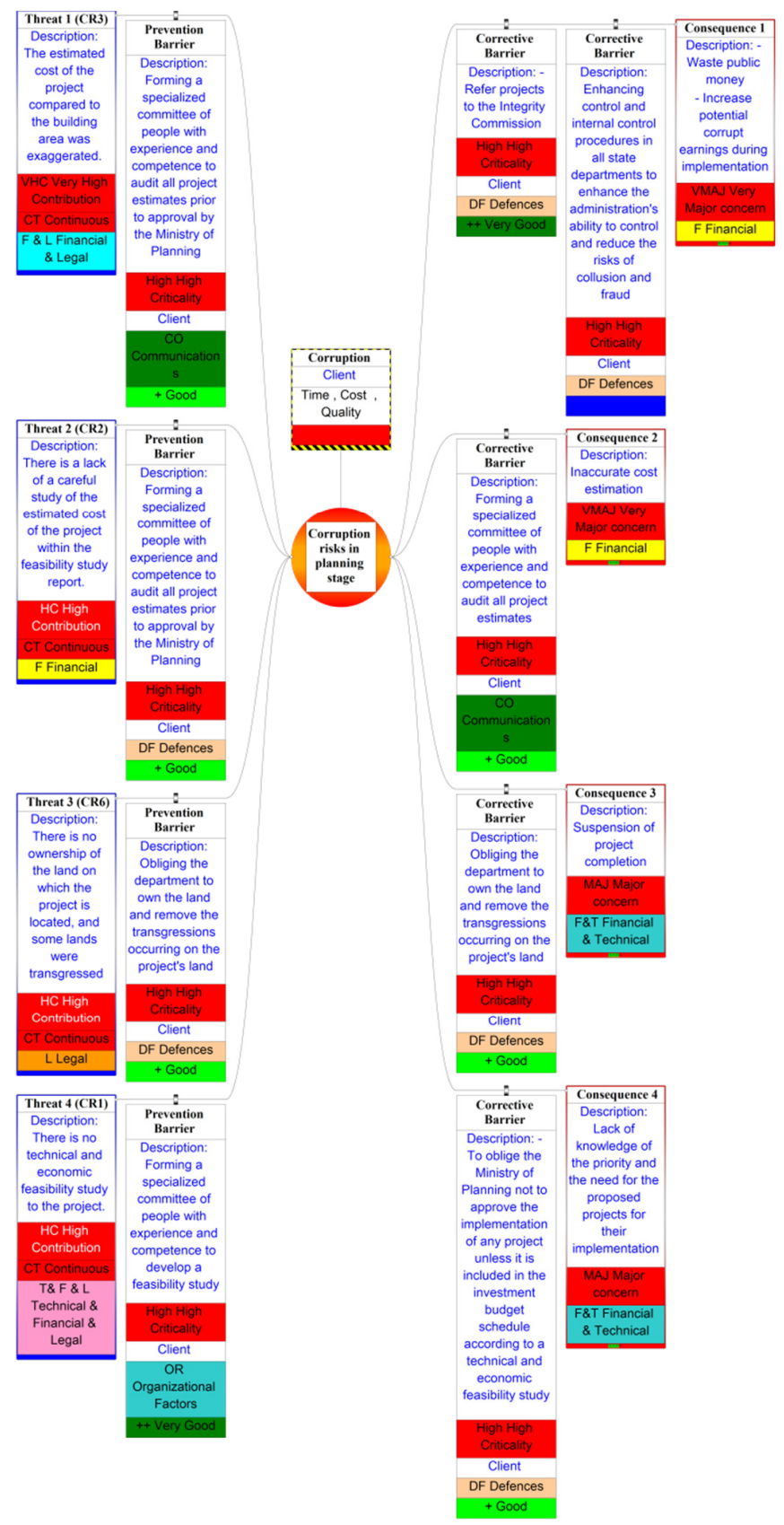

Fig. 3. Bowtie diagram of corruption risks in the planning stage . 


\section{CONCLUSION}

The bowtie methodology is considered to have high flexibility regarding corruption risk management. At the same time, its adaptability might be improved by the use of some adequate tools. On the basis of the system approach, bowtie methodology helps auditors and managers responsible for creating the project plan with the necessary requirements from the estimation cost of the project, offering a technical and economic feasibility study. The conception of threats, consequences, and barriers in the bowtie diagrams facilitate the comprehension regarding the protection and prevention actions needed for corruption risks. Typically, the bowtie has the ability to be vital in managing the corruption risks that we can process before they appear by taking proactive actions for these threats. The bowtie methodology was used to demonstrate the effectiveness of corruption risk management in construction projects in Iraq. The use of BowTie software assists in the analysis and management of hazard and risks in any sector. It provides reports and documents all information that will be used in risk management and supports the audits in the government institutions.

\section{RISK MANAGEMENT RECOMMENDATIONS}

A set of recommendations regarding risk management for corruption-related risks follows:

- A study combining bowtie methodology and simulation model should be conducted.

- There is a need to identify the corruption risks in other stages of the construction sector and appropriate quantitative risk analysis should be conducted.

- The application of the bowtie methodology should be expanded in other sectors such as the safety risk management in construction projects.

\section{ACKNOWLEDGEMENT}

This paper was produced in cooperation with the Department of Civil Engineering, University of Baghdad.

\section{REFERENCES}

[1] "Corruption Perception Index (CPI) 2015," Transparency International. https://www.transparency.org/en/cpi/2015 (accessed May 08, 2021).

[2] P. Zou, "Strategies for Minimizing Corruption in the Construction Industry in China," Journal of Construction in Developing Countries, vol. 11, no. 2, pp. 15-29, Dec. 2006.

[3] E. K. Owusu, A. P. C. Chan, and M. Shan, "Causal Factors of Corruption in Construction Project Management: An Overview," Science and Engineering Ethics, vol. 25, no. 1, pp. 1-31, Feb. 2019, https://doi.org/10.1007/s1 1948-017-0002-4.

[4] N. A. I. M. Saim, I. A. Rahman, and M. F. Ismail, "Factors Contributing to Fraudulent Practices in Construction Project Life Cycle," International Journal of Engineering \& Technology, vol. 7, pp. 647651, Aug. 2018, https://doi.org/10.14419/ijet.v7i3.20.22965.

[5] T. Y. Al-Tai, "The role of performance audit in rationalizing investment decisions for infrastructure projects," Ph.D. dissertation, Baghdad University, Baghdad, Iraq, 2014.

[6] M. Shan, Y. Le, K. T. W. Yiu, A. P. C. Chan, Y. Hu, and Y. Zhou, "Assessing collusion risks in managing construction projects using artificial neural network," Technological and Economic Development of Economy, vol. 24, no. 5, pp. 2003-2025, Oct. 2018, https://doi.org/ $10.3846 / 20294913.2017 .1303648$.
[7] P. T. Nguyen and P. C. Nguyen, "Risk Management in Engineering and Construction: A Case Study in Design-Build Projects in Vietnam," Engineering, Technology \& Applied Science Research, vol. 10, no. 1, pp. 5237-5241, Feb. 2020, https://doi.org/10.48084/etasr.3286.

[8] F. A. Soomro, M. J. Memon, A. F. Chandio, S. Sohu, and R. Soomro, "Causes of Time Overrun in Construction of Building Projects in Pakistan," Engineering, Technology \& Applied Science Research, vol. 9, no. 1, pp. 3762-3764, Feb. 2019, https://doi.org/10.48084/etasr.2449.

[9] A. Lidstone, "The Use of Bowties to Aid the Management of Risk," 2017.

[10] I. Voicu, F. V. Panaitescu, M. Panaitescu, L. G. Dumitrescu, and M. Turof, "Risk management with Bowtie diagrams," IOP Conference Series: Materials Science and Engineering, vol. 400, p. 082021, Sep. 2018, https://doi.org/10.1088/1757-899X/400/8/082021.

[11] D. Allen, Risk Management in Business. Cambridge, UK: Cambridge University Press, 1995.

[12] $P M B O K \circledR$ Guide - A Guide to the Project Management Body of Knowledge, 6th ed. PMI (Project Management Institute, 2107.

[13] "Ministry of Planning Government Implementation Instructions No. (1) for the year 2008." Ministry of Planning, 2008, [Online]. Available: https://mop.gov.iq/static/uploads/7/pdf/151012302174946107c03fdf610 a3ea1241cbc53a2--file1.pdf.

[14] M. Sohail and S. Cavill, "Accountability to Prevent Corruption in Construction Projects," Journal of Construction Engineering and Management, vol. 134, no. 9, pp. 729-738, Sep. 2008, https://doi.org/ 10.1061/(ASCE)0733-9364(2008) 134:9(729).

[15] J. Hawkins, "How to Note: Reducing corruption in infrastructure sectors," Department for International Development, Jan. 2013, http://dx.doi.org/10.12774/eod_cr.may2013.hawkins.

[16] "BowTieXP Virtual Risk Assessment," CGE Risk. https://www.cgerisk. com/products/bowtiexp/ (accessed May 08, 2021) 